\title{
EVOLUÇÃO ANUAL DA QUALIDADE DO LEITE CRU DE TANQUES INDIVIDUAIS E COMUNITÁRIOS DO VALE DO RIO DOCE (MG)
}

\author{
ADRIANO FRANÇA DA CUNHA* \\ HENRIQUE ZAMPIER FERREIRA COSTA** \\ THALES FERREIRA MARCONDES SANTOS** \\ SIMONE QUINTÃO SILVA*** \\ FERNANDO NOGUEIRA DE SOUZA**** \\ MÔNICA MARIA OLIVEIRA PINHO CERQUEIRA*****
}

\begin{abstract}
A qualidade do leite produzido nas propriedades rurais reflete o manejo nutricional, higiênico e sanitário dos animais. Portanto, o objetivo deste trabalho foi avaliar a qualidade de leites crus refrigerados estocados em tanques individuais e comunitários de propriedades rurais do Vale do Rio Doce (MG) ao longo do ano. Nos anos de 2010 a 2012, amostras de leite de 109 tanques comunitários e 115 individuais foram analisadas mensalmente quanto aos teores de proteína, gordura, sólidos totais, CCS e contagem bacteriana. Observou-se que os teores de gordura, proteína e sólidos totais dos leites, tanto de tanques individuais quanto comunitários, variam significativamente $(p<0,05)$ ao longo do ano, sendo que os maiores teores e contagens foram observados em épocas de maiores precipitações de chuvas e temperaturas. Leites de tanques comunitários apresentam predominantemente maiores contagens bacterianas que leites de tanques individuais ao longo do ano. Todas as médias mensais dos parâmetros avaliados se enquadram aos parâmetros legais estabelecidos pela legislação brasileira, exceto as médias de contagem bacteriana. É necessário rever falhas durante as práticas de ordenha e limpeza do ambiente dos animais.
\end{abstract}

PALAVRAS-CHAVE: LEITE; QUALIDADE; COMPOSIÇÃO; BACTÉRIA; SAZONALIDADE; LEGISLAÇÃO

\footnotetext{
* Doutorando em Ciência Animal - Faculdade de Ciências Biológicas e da Saúde (e-mail: adrianofcunha@ hotmail.com.br)

** Graduado em Medicina Veterinária - Faculdade de Ciências Biológicas e da Saúde (henriquezampier@ hotmail.com; thalesmfsantos@hotmail.com)

*** Doutoranda em Microbiologia Agrícola - Universidade Paulista Júlio de Mesquita (simoneufv@yahoo.com. br)

**** Doutorando em Ciência Animal - Universidade Federal de Minas Gerais (nogueirasouza@yahoo.com.br)

***** Doutora em Ciência Animal - Universidade Federal de Minas Gerais (monicapinhocerqueira@gmail.com)
} 


\section{INTRODUÇÃO}

O Brasil ocupa a quinta posição na lista dos maiores países produtores de leite, sendo que a produção em 2013 foi estimada em 32,4 bilhões de litros (MING, 2013). Apesar do grande aumento da produção de leite nos últimos anos no país, a qualidade físico-química e microbiológica do produto é um dos fatores que limitam a conquista de novos mercados (MARTINS et al., 2006; ROSA et al., 2007; BUENO et al., 2008; NERO et al., 2009; AMARAL e SANTOS, 2011).

A qualidade do leite é determinada principalmente pela sua composição nutricional e contaminação bacteriana. Os nutrientes que compõem o produto incluem água (87\%) e os sólidos totais: lactose $(4,9 \%)$, gordura $(3,9 \%)$, proteína $(3,5 \%)$, minerais $(0,7 \%)$ e vitaminas $(0,3 \%)$ (GONZALEZ et al., 2004). Devido à sua riqueza em nutrientes, o leite é suscetível ao ataque de grande número de microrganismos, provenientes do próprio animal, do homem e dos utensílios usados na ordenha. Muitos desses microrganismos podem comprometer a saúde humana (LEITE, 2002; MENDES, 2006).

Uma das principais enfermidades que comprometem a qualidade do leite é a mastite, inflamação da glândula mamária ocasionada principalmente por patógenos bacterianos. Além de diminuir os teores de constituintes e alterar o equilíbrio iônico, a doença ocasiona aumento de células somáticas do leite. Estas são células de descamação do epitélio mamário e células inflamatórias da corrente sanguínea, que acabam caindo no leite devido à resposta imunológica (MACHADO et al., 2000; CERQUEIRA et al., 2010).

O conhecimento da composição do leite e de suas variações é de suma importância para o médico veterinário, como meio de monitorar efeitos da alimentação ou detectar transtornos metabólicos do animal. Além disso, é ferramenta imprescindível para laticínios e produtores, em razão dos prejuízos que podem ocorrer durante o processamento industrial do leite e em razão das bonificações por melhor qualidade ao pagamento feito pelos laticínios (GONZALEZ et al., 2004).

A falta de resfriamento do leite na propriedade rural é outro fator que compromete sua qualidade, em razão da alta taxa de multiplicação dos microrganismos. Para pequenos produtores, o grande desafio é a incapacidade de investir em tanques de resfriamento individual. Com isso, a opção é montar grupos formais ou informais para a aquisição de tanques coletivos (comunitários). Nesse sistema, utiliza-se um único tanque de expansão, o qual é instalado em uma propriedade que recebe o leite de propriedades vizinhas (RIBEIRO e TEIXEIRA, 2000).

Uma vez que o tanque passa a ser unidade de coleta de leite, fica difícil estabelecer critérios específicos para cada produtor. Isso exige um nível de responsabilidade e de interação maior por parte do grupo proprietário do tanque, mas muitas vezes ocasiona problemas operacionais que limitam a obtenção de leite de boa qualidade. Nesse sistema, o leite é submetido a maior manipulação e tem contato com um grande número de equipamentos e utensílios, o que aumenta o risco de contaminação microbiana (FONSECA, 1998; BRITO et al., 2009).

A composição do leite pode oscilar de acordo com a quantidade e a qualidade de forrageira oferecida aos animais, o que, muitas vezes, não é alcançado pelos pequenos produtores. Ademais, a sazonalidade dada pelo volume de chuvas e pelas temperaturas ao longo do ano influencia a qualidade do leite produzido (BUENO et al., 2005; MARTINS et al., 2006, NORO et al., 2006; ROMA Jr et al., 2009). Portanto, o objetivo deste trabalho foi avaliar a evolução da composição e a contagem bacteriana do leite cru refrigerado obtido de tanques individuais e comunitários de propriedades rurais do Vale do Rio Doce (MG) ao longo do ano. 


\section{MATERIAL E MÉTODOS}

Amostras de leite cru refrigerado estocadas em 109 tanques comunitários e 115 tanques individuais de propriedades leiteiras da região do Vale do Rio Doce (MG) foram coletadas mensalmente, no período de janeiro de 2010 a dezembro de 2012.

O leite foi homogeneizado automaticamente nos tanques de refrigeração, durante cinco a dez minutos, pelas pás presentes no equipamento. Posteriormente, alíquotas de aproximadamente $40 \mathrm{ml}$ foram coletadas, por meio de "concha flambada" com álcool $70{ }^{\circ} \mathrm{C}$, em dois frascos "Pleion" estéreis, cada um contendo pastilhas do conservante Bronopol ${ }^{\circledR}$, para determinação da composição e das células somáticas, e Azidiol ${ }^{\circledR}$, para determinação da contagem bacteriana (BRITO, 2007).

Após a identificação dos potes, as amostras foram agitadas para diluição dos conservantes e acondicionadas em caixas isotérmicas contendo gelo reciclável. As caixas foram enviadas para - laboratório da Empresa Brasileira de Pesquisa Agropecuária (Embrapa) em Coronel Pacheco (MG), pertencente à Rede Brasileira de Laboratórios de Análise da Qualidade do Leite (RBQL) e credenciado pelo Ministério da Agricultura, Pecuária e Abastecimento (Mapa).

Os teores de gordura, proteína e sólidos totais, também chamados de extrato seco total (EST), foram determinados por meio de absorção da luz infravermelha e da contagem de células somáticas (CCS) por meio de citometria de fluxo, utilizando o equipamento Bentley Combi System $2300^{\circledR}$ (Bentley Instruments Incorporated, Chaska, USA). Os teores composicionais foram expressos em porcentagens, e a CCS, em cél./ml.

A contagem bacteriana foi realizada por meio do contador eletrônico BactoCount IBC ${ }^{\circledR}$ (Bentley Instruments Incorporated, Chaska, USA), que tem como princípio a citometria de fluxo. O resultado da análise foi expresso em unidades formadoras de colônia por $\mathrm{ml}$ (UFC/ml).

Os dados obtidos ao longo dos três anos de experimento foram convertidos a médias mensais para comparação mês a mês ao longo de um ano, a fim de verificar a influência da sazonalidade anual na qualidade do leite. Dados de precipitação de chuvas $(\mathrm{mm})$ e de temperaturas $\left({ }^{\circ} \mathrm{C}\right)$ mensais ao longo dos anos de 2010 a 2012 foram obtidos por meio do Instituto Nacional de Meteorologia (INMET, 2013) para verificar a influência da sazonalidade sobre a qualidade do leite.

Após a verificação da normalidade por meio do teste de Shapiro-Wilk, os dados de composição do leite foram comparados entre meses pelo teste paramétrico de Tukey, após análise de variâncias (ANOVA). Para comparações entre composição do leite individual e comunitário no mesmo mês, os dados foram submetidos ao teste t de Student com variâncias iguais.

Os dados de CCS e contagem bacteriana foram comparados entre meses pelo teste não paramétrico de Friedman. Para comparações da CCS e contagem bacteriana entre leite individual e comunitário no mesmo mês, os dados foram submetidos ao teste de Mann-Whitney.

Todos os testes foram analisados ao nível de $5 \%$ de significância, utilizando o programa computacional Statistical Package for the Social Sciences 20.0 (SPSS Inc., Chicago, USA). A qualidade do leite ainda foi analisada quanto aos parâmetros estabelecidos pela Instrução Normativa n62, do Mapa (BRASIL, 2011).

\section{RESULTADOS E DISCUSSÃO}

Nos meses finais e iniciais do ano, houve registro de maiores volumes de chuvas e temperaturas, exceto em fevereiro, no qual houve estiagem (figura 1). As precipitações de chuvas e as temperaturas são parâmetros que influenciam a disponibilidade de capim, o que determina maior síntese de leite na glândula mamária e maior composição dos seus constituintes (TEIXEIRA et al., 2003; NORO et al., 2006; ROMA Jr et al., 2009). 


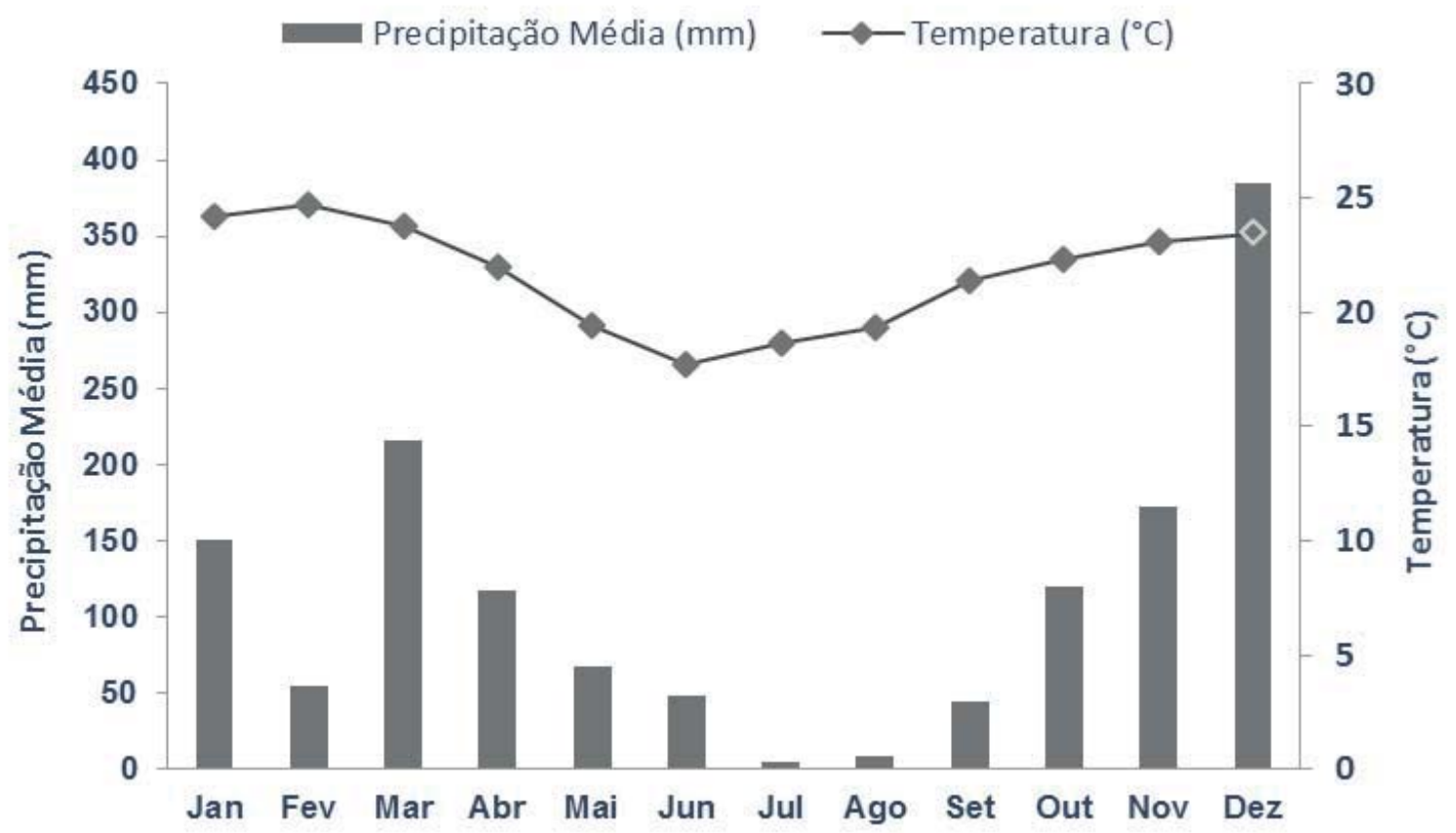

FIGURA 1 - PRECIPITAÇÃO DE CHUVAS E TEMPERATURAS MÉDIAS MENSAIS NA REGIÃO DO VALE DO RIO DOCE (MG) NOS ANOS DE 2010 A 2012

Ao longo do ano, observou-se variação significativa $(p<0,05)$ dos teores médios de proteína dos leites, tanto de tanques individuais quanto comunitários (figura 2). Nos meses caracterizados por apresentarem menores volumes de chuva (figura 1), os teores de proteína tenderam a ser menores, enquanto nos meses mais chuvosos os teores tenderam a ser maiores. No entanto, todas as médias apresentaram-se dentro do limite mínimo de 2,9\% estabelecido pela legislação brasileira (BRASIL, 2011).

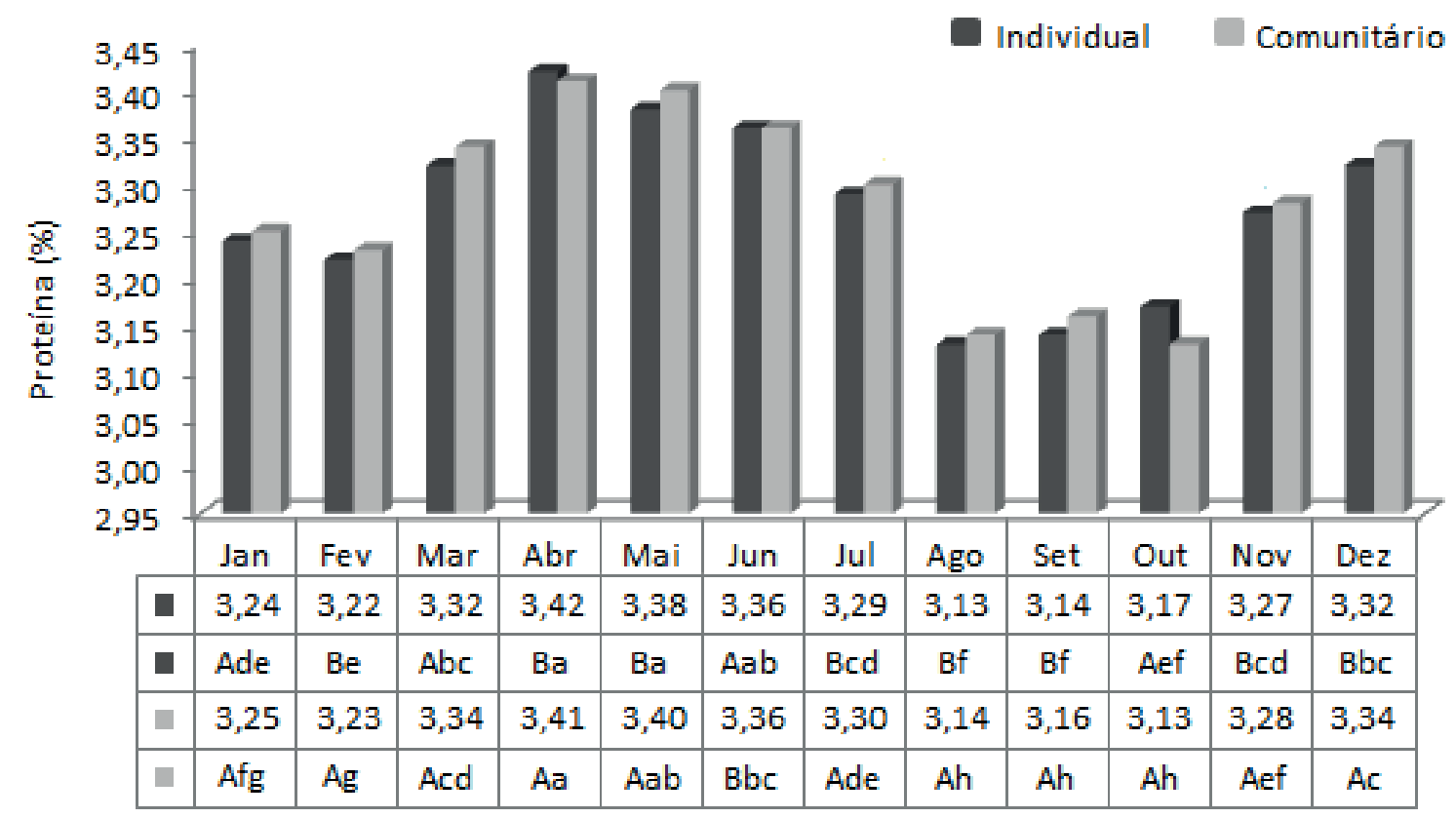

FIGURA 2 - VARIAÇÃO MENSAL DO TEOR MÉDIO DE PROTEÍNA DO LEITE CRU REFRIGERADO INDIVIDUAL E COMUNITÁRIO DE PROPRIEDADES RURAIS DO VALE DO RIO DOCE (MG)

Letras maiúsculas distintas entre linhas diferem pelo teste t de Student $(p<0,05)$ e letras minúsculas entre colunas diferem pelo teste de Tukey $(p<0,05)$ 
No inverno e início da primavera, os pastos estão com capim de baixa qualidade devido à falta de chuva, o que faz com que o alimento não atenda às exigências nutricionais dos animais para que produzam leite com alto teor de proteína (TEIXEIRA et al., 2003; PAIVA et al., 2012). Além disso, o sistema de criação na maioria das propriedades avaliadas era extensivo. Nele, os animais ficam mais dependentes do pastejo, que, associado à falta de volumoso de qualidade e à baixa suplementação proteica, faz com que o teor de proteína do leite seja baixo (ROMA Jr et al., 2009).

Os teores médios de proteína entre leite de tanque individual e comunitário foram diferentes $(p<0,05)$, exceto nos meses de janeiro, março e outubro ( $p>0,05)$. Segundo Paiva (2012), essa variação nos teores de proteína tem como principal causa o efeito diluição. Misturado aos tanques comunitários, o leite com alto teor de proteína de algumas propriedades acaba compensando o leite com baixo teor de proteína de outras propriedades. Com isso, o leite de tanques comunitários apresenta menores variações porcentuais que o leite de tanques individuais.

Os teores médios de gordura dos leites, tanto de tanques individuais quanto comunitários, variaram significativamente $(p<0,05)$ ao longo do ano (figura 3). De forma geral, menores teores de gordura foram observados nos meses finais e iniciais do ano, enquanto os maiores teores foram observados no outono. Apesar disso, todas as médias apresentaram-se dentro do limite mínimo de $3 \%$ estabelecido pela legislação (BRASIL, 2011).

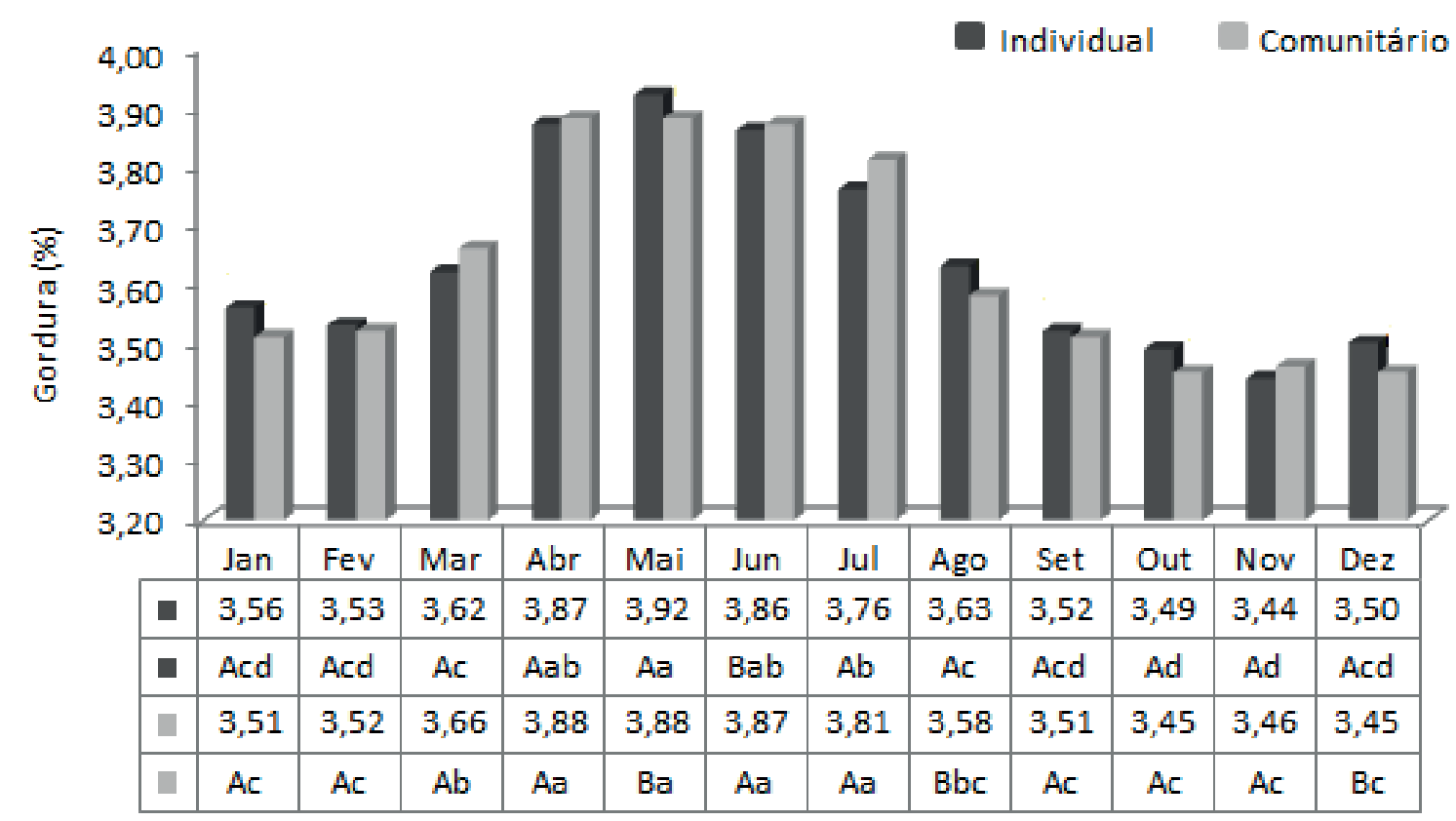

\section{FIGURA 3 - VARIAÇÃO MENSAL DO TEOR MÉDIO DE GORDURA DO LEITE CRU REFRIGERADO INDIVIDUAL E COMUNITÁRIO DE PROPRIEDADES RURAIS DO VALE DO RIO DOCE (MG)}

Letras maiúsculas distintas entre linhas diferem pelo teste t de Student $(p<0,05)$ e letras minúsculas entre colunas diferem pelo teste de Tukey $(p<0,05)$

Peres (2001) relatou que a maior porcentagem de gordura no leite é causada pelas maiores porcentagens molares de ácido acético e butírico no rúmen do animal, o que é influenciado pela maior oferta de volumoso. No verão, observa-se quantidade maior de volumoso e de melhor qualidade. Consequentemente, o leite apresenta maior teor de gordura, o que não foi visto no presente trabalho. Os baixos teores médios de gordura observados no outono se justificam pela estiagem observada em fevereiro e pelo fato de a oferta de capim ser maior após o início das chuvas, pois ainda deve ocorrer o crescimento do capim, determinado pelo comprimento final das lâminas foliares e pela densidade populacional de perfilhos na planta (PACILULLO et al., 2008). 
Os teores de gordura do leite são mais dependentes da oferta de volumoso que os teores de proteína, pois a fibra digestível do volumoso é a principal fonte para os microrganismos ruminais produzirem acetato e butirato, precursores da síntese de gordura na glândula mamária (PERES, 2001). Isso, associado ao fato de alguns produtores ainda suplementarem a dieta animal com concentrado proteico, explica a diferença na evolução dos teores de gordura e proteína dada entre os meses de novembro e fevereiro.

Nos meses de maio, junho, agosto e dezembro, os teores médios de gordura entre leite de tanque individual e leite de tanque comunitário foram significativamente diferentes $(p<0,05)$. A gordura do leite é o constituinte que apresenta maior variação percentual. Os fatores que podem ter influenciado a diferença nos teores de gordura são genética, período de lactação dos animais e o fato de que, em pequenas propriedades, a oferta de volumoso aos animais tende a ser menor que em grandes propriedades leiteiras (GONZALEZ et al., 2004).

Também houve variação significativa $(p<0,05)$ dos teores médios de EST dos leites ao longo do ano (figura 4). Como a gordura e a proteína fazem parte dos sólidos totais, os teores de EST tendem a variar de forma semelhante à gordura e à proteína (PAIVA et al., 2012). Nos meses em que houve maiores precipitações pluviométricas, ou seja, verão e início do outono (figura 1), os teores de EST tenderam a ser maiores, tanto para leite de tanques individuais quanto comunitários. Os baixos teores médios de gordura observados no verão, determinados pela estiagem de fevereiro, influenciaram os teores de EST em tal estação, fazendo com que os teores de tal constituinte fossem maiores no outono.

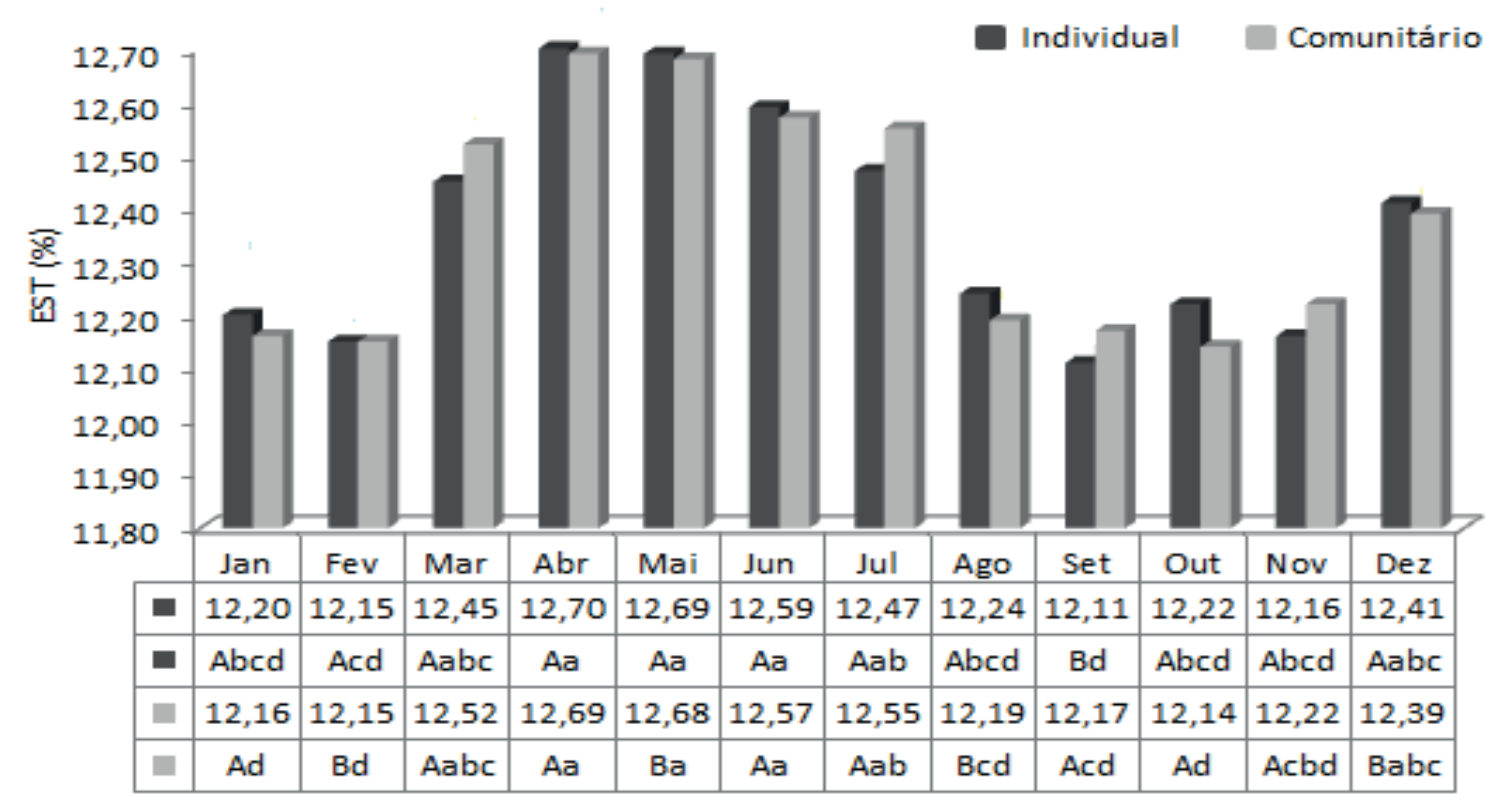

\section{FIGURA 4 - VARIAÇÃO MENSAL DO TEOR MÉDIO DE EST DO LEITE CRU REFRIGERADO INDIVIDUAL E COMUNITÁRIO DE PROPRIEDADES RURAIS DO VALE DO RIO DOCE (MG)}

Letras maiúsculas distintas entre linhas diferem pelo teste t de Student $(p<0,05)$ e letras minúsculas entre colunas diferem pelo teste de Tukey $(p<0,05)$

Nos meses de fevereiro, maio, agosto, setembro e dezembro, os teores médios de EST entre leite de tanque individual e comunitário foram significativamente diferentes $(p<0,05)$. Fatores como genética, período e ordem de lactação podem ter contribuído para tais discrepâncias (GONZALEZ et al., 2004). Contudo, todas as médias apresentaram-se dentro do limite mínimo de $11,4 \%$ estabelecido pela legislação (BRASIL, 2011). 
Apesar de apresentaram-se dentro do limite máximo de 600.000 cél./ml estabelecido pela legislação (BRASIL, 2011), as CCS médias dos leites variaram significativamente $(p<0,05)$ ao longo do ano (figura 5). Maiores CCS tenderam a ocorrer nos meses com maiores precipitações de chuva (figura 1), exceto em fevereiro. A alta CCS observada nesse mês pode ser explicada pelo fato de tal parâmetro ser mais dependente da resposta fisiológica animal do que os teores de gordura e proteína. A CCS não aumenta ou diminui repentinamente de um mês para outro em razão da resposta imunológica (MACHADO et al., 2000).

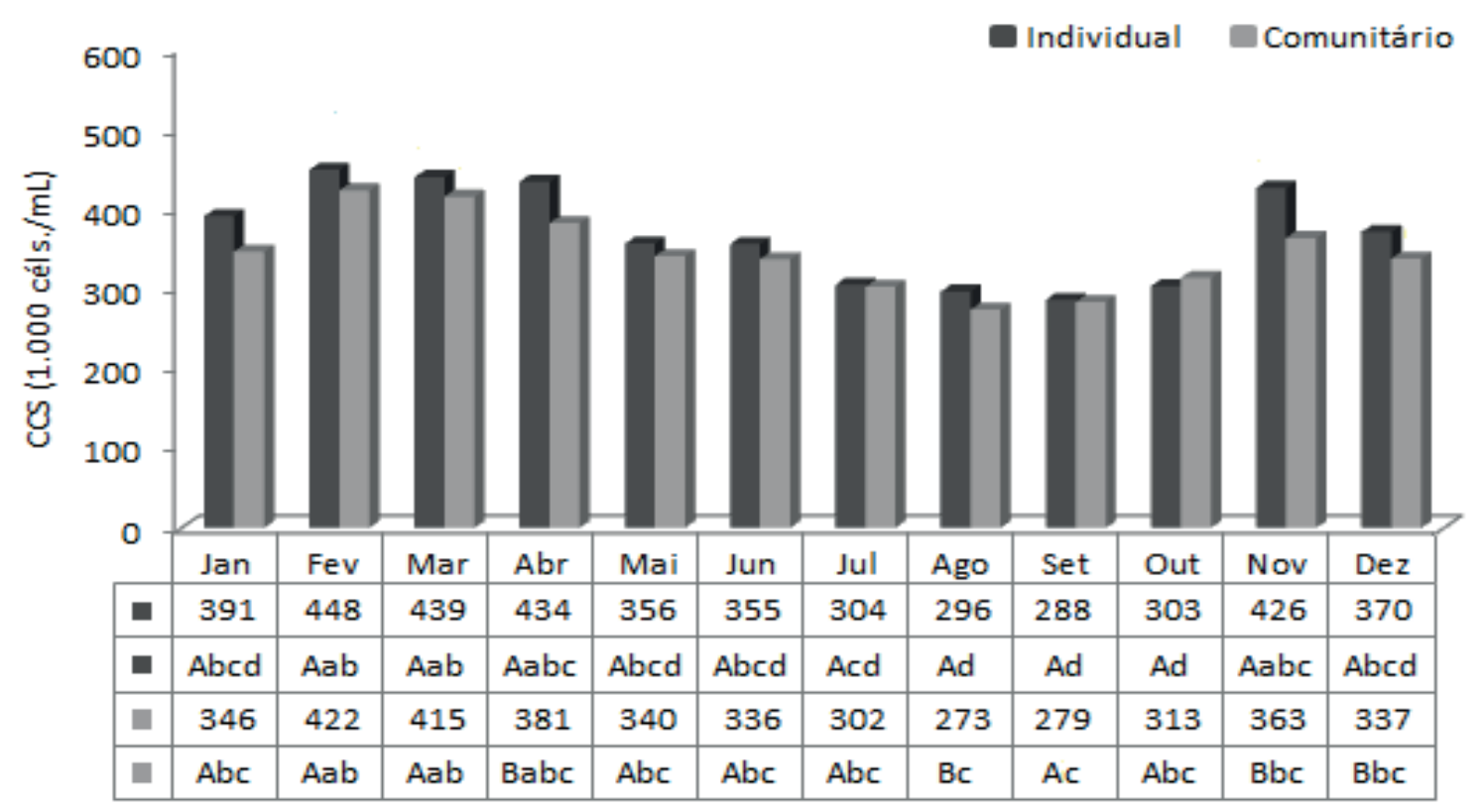

\section{FIGURA 5 - VARIAÇÃO MENSAL DA CCS DO LEITE CRU REFRIGERADO INDIVIDUAL E COMUNITÁRIO DE PROPRIEDADES RURAIS DO VALE DO RIO DOCE (MG)}

Letras maiúsculas distintas entre colunas diferem pelo teste Mann-Whitney $(p<0,05)$ e letras minúsculas entre colunas diferem pelo teste de Friedman $(p<0,05)$

Em épocas de alta temperatura e umidade, os animais apresentam menor capacidade de resposta a doenças devido ao estresse. Os microrganismos apesentam maior proliferação e há maior acúmulo de matéria orgânica no ambiente dos animais, dificultando a higiene durante a ordenha. Tais fatores podem ter aumentado a exposição dos animais aos agentes causadores de mastite, o que aumenta a CCS do leite do tanque (MACHADO et al., 2000).

Observou-se que, nos meses de abril, agosto, novembro e dezembro, as CCS médias entre leites de tanque individual e comunitário foram significativamente diferentes $(p<0,05)$. Tal fato pode estar associado às diferenças de manejo das propriedades, como: práticas de controle sanitário do rebanho, higienização de equipamentos, funcionários, animais e instalações no momento da ordenha e alimentação do rebanho, pois a inadequada oferta de volumoso dificulta a resposta imunológica do animal contra patógenos causadores de mastite (MARTINS et al., 2008; CERQUEIRA et al., 2010).

As contagens bacterianas médias dos leites, tanto de tanques individuais quanto comunitários, variaram significativamente $(p<0,05)$ ao longo do ano (figura 6$)$. Todas as contagens médias dos leites de tanques comunitários apresentaram-se acima do limite máximo estabelecido pela legislação, ou seja, $600.000 \mathrm{UFC/ml} \mathrm{(BRASIL,} \mathrm{2011).} \mathrm{Quanto} \mathrm{aos} \mathrm{leites} \mathrm{de} \mathrm{tanques} \mathrm{individuais,}$ as contagens apresentaram-se acima do limite nos meses que compreendem o período de novembro a março. 


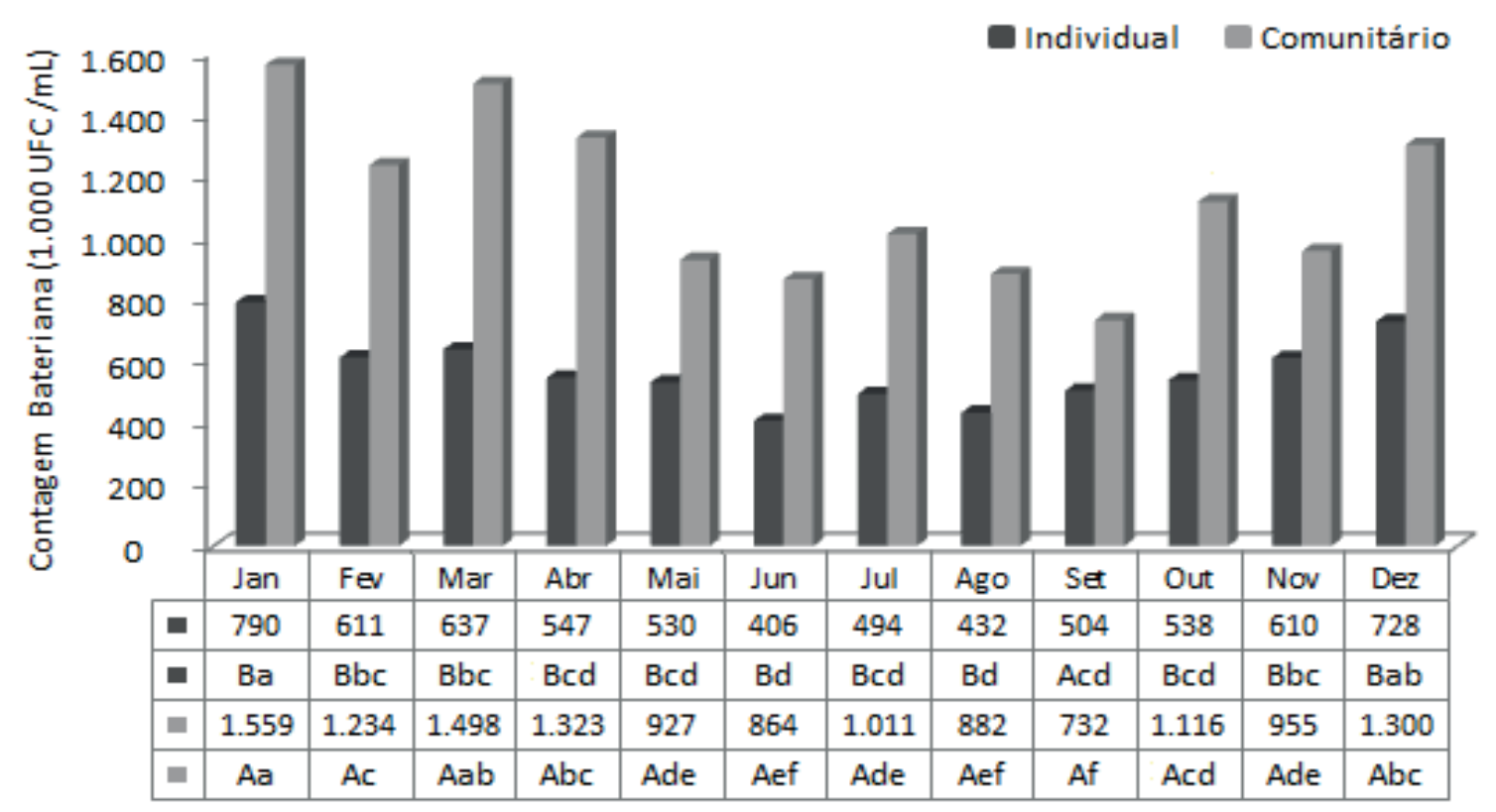

\section{FIGURA 6 - VARIAÇÃO MENSAL DA CONTAGEM BACTERIANA DO LEITE CRU REFRIGERADO INDIVIDUAL E COMUNITÁRIO DE PROPRIEDADES RURAIS DO VALE DO RIO DOCE (MG)}

Letras maiúsculas distintas entre colunas diferem pelo teste Mann-Whitney $(p<0,05)$ e letras minúsculas entre colunas diferem pelo teste de Friedman $(p<0,05)$

Maiores contagens bacterianas foram observadas nos meses com precipitações de chuva e temperaturas elevadas. BUENO et al. (2008) também observaram leites com maiores contagens bacterianas na época de chuvas e menores na época da seca. $O$ aumento das chuvas favorece a contaminação ambiental, o acúmulo de lama nas instalações e maior ocorrência de tetos sujos no momento da ordenha. Esses fatores, associados às falhas na rotina de ordenha, causam elevada contaminação do leite (MARTINS et al., 2006; CITADIN et al., 2009).

Durante as coletas nas propriedades, falhas durante a limpeza e sanitização dos equipamentos de ordenha e do tanque resfriador foram verificadas, bem como manejo inadequado durante a ordenha e acúmulo de matéria orgânica no ambiente dos animais. Essas falhas culminam no aumento da contagem bacteriana, causando perdas na qualidade do leite e prejuízos para o produtor, para a indústria e para o consumidor. A maior parte das indústrias bonifica o leite de melhor qualidade em razão de a matéria-prima ser determinante no rendimento dos derivados lácteos. Para o consumidor, a alta contagem bacteriana pode comprometer sua saúde (FIGUEIREDO et al., 2012).

As contagens bacterianas médias entre leites de tanques individuais e comunitários foram significativamente diferentes $(p<0,05)$, exceto em setembro. $O$ leite de tanques comunitários apresentara maiores contagens bacterianas ao longo do ano. Segundo BRITO et al. (2009), o leite de tanques coletivos apresenta altas contagens bacterianas em razão das deficiências individuais dos produtores no ato de higiene, o que compromete a qualidade microbiológica na produção. $O$ tempo em que o leite fica sem refrigeração, desde a ordenha até o armazenamento no tanque comunitário, propicia maior proliferação bacteriana.

\section{CONCLUSÕES}

A qualidade do leite cru refrigerado de tanques individuais e comunitários de propriedades leiteiras da região do Vale do Rio Doce (MG) varia ao longo do ano. As maiores precipitações 
pluviométricas e temperaturas dadas pela sazonalidade propiciam maiores teores de sólidos no leite, mas aumentam a CCS e a contagem bacteriana.

Os leites de tanques comunitários têm contagens bacterianas médias em desacordo com a legislação e apresentam predominantemente maiores contagens bacterianas que o leite de tanques individuais ao longo do ano. É necessário rever as falhas durante as práticas de ordenha e o acúmulo de matéria orgânica no ambiente dos animais.

\section{ABSTRACT \\ ANNUAL EVOLUTION QUALITY OF RAW MILK FROM INDIVIDUAL AND COMMUNITY TANKS OF VALE DO RIO DOCE (MG)}

The quality of milk produced in dairy farms reflects the nutritional, hygienic and sanitary handling of animals. Therefore, the objective of this study was to evaluate the quality of refrigerated raw milk stored in individual and community tanks of farms in Vale do Rio Doce (MG), along the year. From 2010 to 2012, milk samples from 109 individual and 115 community tanks were analyzed monthly as for the tenors of protein, fat, total solids, SCC and bacterial counts. It was observed that the tenors of fat, protein and total solids of milk, both as individual and community tanks, vary significantly $(p<0.05)$ along the year. Highest tenors and counts were observed at season with greatest precipitation of rain and temperatures. Milk from community tanks have predominantly larger bacterial counts than milk from individual tanks along the year. All monthly means of the evaluated parameters fit the legal parameters established by Brazilian legislation, except the bacterial count mean. It is necessary to review failures during milking practices and cleanliness of the environment of the animals.

KEY WORDS: MILK, QUALITY, COMPOSITION, BACTERIA, SEASONALITY, LEGISLATION

\section{REFERÊNCIAS}

1. AMARAL, C.R.S.; SANTOS, E.P. Leite cru comercializado na cidade de Solânea, PB: caracterização físico-química e microbiológica. Revista Brasileira de Produtos Agroindustriais, v.13, n.1, p.7-13, 2011

2. BRASIL, Ministério da Agricultura, Pecuária e Abastecimento. Instrução Normativa n 62, de 29 de dezembro de 2011. Altera a Instrução Normativa $n^{\circ} 51$, de 18 de setembro de 2002. Regulamento Técnico de Produção, Identidade e Qualidade do Leite tipo A, Leite Cru Refrigerado, Leite Pasteurizado e Coleta de Leite Cru Refrigerado e seu Transporte a Granel. Diário Oficial da União, Brasília, DF, 29 de dezembro de 2011.

3. BRITO, J.R.F.; SOUZA, G.N.; FARIA, C.G.; MORAES, L.C.D. Procedimentos para coleta e envio de amostras de leite para determinação da composição e das contagens de células somáticas e de bactérias. Juiz de Fora: Embrapa Gado de Leite, Circular Técnica Circular Técnica 92, 2007. 8p.

4. BRITO, M.A.V.P.; SOUZA, G.N.; LANGE, C.C.; BRITO, J.R.F. Qualidade do leite armazenado em tanques coletivos. Juiz de Fora: Embrapa Gado de Leite, Circular Técnica 99, 2009. 8p.

5. BUENO, V.F.F.; MESQUITA, A.J.; NICOLAU, E.S.; OLIVEIRA, A.N.; OLIVEIRA, J.P.; NEVES, R.B.S.; MANSUR, J.R.G.; THOMAZ, L.W. Contagem celular somática: relação com composição centesimal do leite e período do ano no Estado de Goiás. Ciência Rural, v.35, n.4, p.848-854, 2005.

6. BUENO, V.F.F.; MESQUITA, A.J.; OLIVEIRA, A.N.; NICOLAU, E.S.; NEVES, R.B.S. Contagem bacteriana total do leite: relação com a composição centesimal e período do ano no Estado de Goiás. Revista Brasileira de Ciência Veterinária, v.15, n.1, p.40-44, 2008.

7. CERQUEIRA, M.M.O.P.; VARGAS, R.T.; CUNHA, A.F.; LAGE, A.D.; FONSECA, L.M.; RODRIGUES, R.; LEITE, M.O.; PENNA, C.F.A.M.; SOUZA, M.R. Mastite em novilhas: importância e controle. Ciência Animal Brasileira, v.10, p.1-21, 2010.

8. CITADIN, A.S.; POZZA, M.S.S.; POZZA, P.C.; NUNES, R.V.; BORSATTI, L.; MANGONI, J. Qualidade microbiológica de leite cru refrigerado e fatores associados. Revista Brasileira de Saúde e Produção Animal, v.10, n.1, p.52-59, 2009. 
9. FIGUEIREDO, A.P.G.; ARAÚJO, M.M.P.; CUNHA, A.F.; ALVES, J.R.; CERQUEIRA, M.M.O.P. Qualidade do leite de propriedades da área de proteção ambiental da bacia do Córrego da Velha no município de Luz (MG). Ciência Equatorial, v.2, n.2, p.34-53, 2012.

10. FONSECA, L.F.L. Leite a granel: modelo moderno de estocagem e transporte. Leite \& Derivados, v.7, n.40, p.16-21, 1998.

11. GONZALES, H.L.; FISCHER, V.; RIBEIRO, M.E.R.; GOMES, J.F.; STUMPF JR, W.; SILVA, M.A. Avaliação da qualidade do leite nos diferentes meses do ano na bacia leiteira de Pelotas, RS. Revista Brasileira de Zootecnia, v.33, n.6, p.15311543,2004

12. INMET, Instituto Nacional de Meteorologia. Estações automáticas: gráficos. 2013. Retirado do site: http://www.inmet.gov. br/portal/index.php?r=home/page\&page=rede estacoes_conv graf Acesso em 01 de junho de 2013.

13. LEITE, C.C.; GUIMARÃES, A.G.; ASSIS, P.N.; SILVA, M.D.; ANDRADE, C.S.O. Qualidade bacteriológica do leite integral (tipo C) comercializado em Salvador - Bahia. Revista Brasileira de Saúde e Produção Animal, v.3, n.1, p.21-25, 2002.

14. MACHADO, P.F.; PEREIRA, A.R.; SARRÍES, G.A. Composição do leite de rebanhos brasileiros distribuídos segundo sua contagem de células somáticas. Revista Brasileira de Zootecnia, p.1883-1886, 2000.

15. MARTINS, M.E.P.; NICOLAU, E.S.; MESQUITA, A.J.; NEVES, R.B.S.; ARRUDA, M.T. Qualidade do leite cru produzido e armazenado em tanques de expansão no estado de Goiás. Revista Ciência Animal Brasileira, v.9, n.4, p.1152-1158, 2008.

16. MARTINS, P.R.G.; SILVA, C.A.; FISCHER, V.; RIBEIRO, M.E.R.; STUMPF JR, W.; ZANELA, M.B. Produção e qualidade do leite na bacia leiteira de Pelotas-RS em diferentes meses do ano. Ciência Rural, v.36, n.1, p.209-214, 2006.

17. MING, P. Brazil: dairy and products annual - annual dairy report. United States Department of Agriculture. 2013, 15p. Disponível em: http://gain.fas.usda.gov/Recent\%20GAIN\%20Publications/Dairy\%20and\%20Products\%20Annual_ Brasilia_Brazil_10-16-2013.pdf Acesso em 11 de janeiro de 2014.

18. NERO, L.A.; VIÇOSA, G.N.; PEREIRA, F.E.V. Qualidade microbiológica do leite determinada por características de produção. Ciência e Tecnologia de Alimentos, v.29, n.2, p.386-390, 2009.

19. NORO, G.; GONZÁLEZ, F. H. D.; CAMPOS, F.; DÜRR, J. W. Fatores ambientais que afetam a produção e a composição do leite em rebanhos assistidos por cooperativas no Rio Grande do Sul. Revista Brasileira de Zootecnia, v. 35, p. 11291135, 2006.

20. PACIULLO, D.S.C.; CAMPOS, N.R.; GOMIDE, C.A.M.; CASTRO, C.R.T.; TAVELA, R.C.; ROSSIELLO, R.O.P. Crescimento de capim-braquiária influenciado pelo grau de sombreamento e pela estação do ano. Pesquisa Agropecuária Brasileira, v.43, n.7, p.917-923, 2008

21. PAIVA, C.A.V.; CERQUEIRA, M.M.O.P.; SOUZA, M.R.; LANNA, A.M.Q. Evolução anual da qualidade do leite cru refrigerado processado em uma indústria de Minas Gerais. Arquivo Brasileiro de Medicina Veterinária e Zootecnia, v.64, p.471/2-478, 2012

22. PERES, J.R. O leite como ferramenta do monitoramento nutricional. In Uso do leite para monitorar a nutrição e o metabolismo de vacas leiteiras. Porto Alegre: Gráfica da Universidade Federal do Rio Grande do Sul, 2001. p.30-45.

23. RIBEIRO, M.T.; TEIXEIRA, S.R.L. Qualidade do leite em tanques de expansão individuais ou comunitários. Revista Glória Rural, v.3, n.38, p.28-35, 2000.

24. ROMA JR., L.C.; MONTOYA, J.F.C.; MARTINS, T.T.; CASSOLI, L.D.; MACHADO, P.F. Sazonalidade do teor de proteína e outros componentes do leite e sua relação com programa de pagamento por qualidade. Arquivo Brasileiro de Medicina Veterinária e Zootecnia, v. 61, n. 6, p.1411-1418, 2009.

25. ROSA, L.S.; QUEIROZ, M.I. Avaliação da qualidade do leite cru resfriado mediante aplicação de princípios do APPCC. Ciência e Tecnologia de Alimentos, v.27, n.2, p.422-430, 2007.

26. TEIXEIRA, N.M.; FREITAS, A.F; BARRA, R.B. Influência de fatores de meio ambiente na variação mensal da composição e contagem de células somáticas do leite em rebanhos no Estado de Minas Gerais. Arquivo Brasileiro de Medicina Veterinária e Zootecnia, v.55, p.4911-499, 2003. 